\title{
KOMPARASI KELENGKAPAN IMUNISASI DASAR PADA BAYI DENGAN IBU YANG BEKERJA DAN TIDAK BEKERJA
}

\author{
ETIKA PURNAMA SARI \\ AKADEMI KEPERAWATAN ADI HUSADA SURABAYA \\ etikaps@gmail.com
}

\begin{abstract}
ABSTRAK
Kelengkapan pemberian imunisasi dasar perlu mendapatkan perhatian khusus dari orang tua terutama para ibu yang bekerja ataupun yang tidak bekerja. Peran ibu sangat mempengaruhi tercapainya kelengkapan imunisasi dasar. Tujuan dari penelitian ini adalah menjelaskan perbedaan kelengkapan imunisasi dasar pada bayi antara ibu yang bekerja dan tidak bekerja. Desain penelitian adalah komparasi dengan pendekatan cross sectional. Variabel yang diteliti adalah kelengkapan imunisasi dasar. Sampel yang digunakan adalah ibu yang memiliki bayi usia 9-12 bulan sebanyak 30 orang. Pengambilan data digunakan dengan observasi status imunisasi pada KMS. Berdasarkan hasil uji Mann Whitney U Test didapatkan nilai $\mathrm{p}=0.133(\alpha<0.05)$ yang berarti tidak ada perbedaan kelengkapan imunisasi dasar pada bayi dengan ibu yang tidak bekerja dan tidak bekerja. Tidak adanya perbedaan dikarenakan pada kelompok ibu yang bekerja dan yang tidak bekerja sebagian berpendidikan tinggi. Bagi para ibu harus tetap memiliki tanggung jawab untuk kelengkapan imunisasi bayinya.
\end{abstract}

Kata kunci: imunisasi, ibu, bekerja

\section{ABSTRACT}

Completeness of basic immunization needs special attention from parents, especially working mothers or were not working. The role of the mother greatly affect the achievement of complete basic immunization. The aim of this study is to explain the differences completeness of basic immunization in infants between mothers working and not working. The study design was comparative with cross-sectional approach. The variables were the completeness of basic immunization. The samples used were mothers with babies aged 9-12 months as many as 30 people. Data was collected by the observation immunization status at KMS. Based on the test results of the Mann Whitney U Test $p=0.133(\alpha<0.05)$ which means there is no difference in the completeness of basic immunization in infants with mothers who are not working and not working. No difference because the group of the mothers who work and who do not work most highly educated. For the mother must continue to have responsibility for the completeness of infant immunization.

Keywords: immunization, mother, work 


\section{PENDAHULUAN}

Program imunisasi merupakan cara terbaik untuk melindungi seseorang dari serangan penyakit yang berbahaya dan juga mematikan khususnya bagi bayi dan anakanak. Pemberian imunisasi dasar merupakan salah satu program yang diwajibkan oleh pemerintah. Pentingnya kelengkapan imunisasi sangat perlu mendapatkan perhatian khusus dari orang tua terutama para ibu. Pemberian kelengkapan imunisasi dasar pada anak tidak selamanya berjalan dengan lancar, meskipun sudah tersedia fasilitas pelayanan untuk imunisasi, beberapa orang tua belum membawa bayinya untuk mendapatkan imunisasi yang lengkap karena banyak faktor, salah satunya adalah pekerjaan. Walaupun pemerintah telah mentargetkan cakupan imunisasi setinggi-tingginya namun pada kenyataannya kegiatan imunisasi masih kurang mendapatkan perhatian dari para ibu yang memiliki balita. ${ }^{1}$

Riset Kesehatan Dasar 2007 melaporkan bahwa 50.000 anak di Indonesia tidak mendapatkan setengah dari vaksin Lima Imunisasi Lengkap. RisKesDas juga mencatat sekitar 46,2\% anak sudah mendapatkan imunisasi secara lengkap dan 45,3\% imunisasinya tidak lengkap ${ }^{2}$. Dari hasil riset penelitian, imunisasi campak merupakan tolak ukur untuk kelengkapan imunisasi, dimana cakupan imunisasi campak tahun 2009 dilaporkan mencapai $92,1 \%$ masih belum merata, masih ada daerah dengan cakupan imunisasi rendah. Cakupan imunisasi tahun 2010 yang telah dilaporkan sampai bulan Agustus hingga September baru mencapai $66,1 \%^{3}$. Berdasarkan survei pendahuluan di Posyandu Cempaka RW 05 Sidomulyo didapatkan 8 bayi usia 9-12 bulan yang belum mendapatkan imunisasi dasar yang lengkap.

Banyak faktor yang menyebabkan kelengkapan imunisasi, faktor tersebut antara lain sikap petugas, lokasi imunisasi, kehadiran petugas, usia ibu, tingkat pendidikan ibu, tingkat pendapatan keluarga per bulan, kepercayaan terhadap dampak buruk pemberian imunisasi, tradisi keluarga, tingkat pengetahuan ibu, dukungan keluarga, dan status pekerjaan ibu ${ }^{4}$.

Hingga saat ini pemerintah masih terus mewajibkan program imunisasi dengan memberikan beberapa solusi seperti mempermudah pelayanan imunisasi, penyediaan fasilitas imunisasi dan pemberian reward atas keikutsertaan dalam program imunisasi.

Tujuan dari penelitian ini adalah untuk menjelaskan perbedaan kelengkapan imunisasi dasar pada bayi antara ibu yang bekerja dan tidak bekerja.

\section{METODE PENELITIAN}

Desain penelitian ini adalah komparasi dengan pendekatan cross sectional. Waktu penelitian pada bulan April 2014. Tempat penelitian di wilayah Posyandu Cempaka RW 05 Sidomulyo Surabaya.

Populasi dalam penelitian ini adalah semua ibu yang memiliki bayi di wilayah Posyandu Cempaka RW 05 Sidomulyo Surabaya. Pengambilan sampel dengan menggunakan purposive sampling dengan kriteria inklusi yaitu ibu yang memiliki bayi usia 9-12 bulan sebanyak 30 orang.

Pengumpulan data dengan wawancara dan observasi Kartu Menuju Sehat (KMS). Analisa data membandingkan dua kelompok independen dengan menggunakan uji statistik Mann Whitney U Test.

\section{HASIL}

Karakteristik responden

Hampir sebagian besar responden (47\%) berusia 20-30 tahun, dan pendidikan responden sebagian besar (60\%) SMA.

Tabel 1 Kelengkapan imunisasi bayi pada ibu bekerja

\begin{tabular}{llll}
\hline No. & Kelengkapan & $\mathbf{n}$ & $\mathbf{\%}$ \\
\hline 1. & Ya & 2 & 22 \\
2. & Tidak & 7 & 78 \\
\hline & Jumlah & 9 & 100 \\
\hline
\end{tabular}

Tabel 1 menunjukkan hampir mayoritas status imunisasi bayi pada ibu yang bekerja tidak lengkap.

Tabel 2 Kelengkapan imunisasi bayi pada ibu tidak bekerja

\begin{tabular}{llll}
\hline No. & Kelengkapan & $\mathbf{n}$ & \% \\
\hline 1. & Ya & 11 & 52 \\
2. & Tidak & 10 & 48 \\
\hline & Jumlah & 21 & 100 \\
\hline
\end{tabular}

Tabel 2 menunjukkan sebagian besar status imunisasi bayi pada ibu yang tidak bekerja lengkap.

Dari hasil uji statistik Mann-Whitney $U$ Test menunjukkan $\mathrm{p}=0.133 \quad(\alpha<0.05)$ yang 
artinya tidak terdapat perbedaan status kelengkapan imunisasi.

\section{PEMBAHASAN}

Hasil analisa data perbandingan dua kelompok independen menunjukkan bahwa nilai $p=0.133 \quad(\alpha<0.05)$, sehingga tidak terdapat perbedaan kelengkapan imunisasi pada bayi antara ibu yang bekerja dan ibu yang tidak bekerja.

Imunisasi (kekebalan) adalah suatu cara meningkatkan kekebalan seseorang secara aktif terhadap suatu antigen, sehingga bila kelak ia terpajan pada antigen yang serupa tidak terjangkit penyakit. ${ }^{5}$ Beberapa manfaat imunisasi bagi bayi dan anak antara lain adalah memperkuat daya tahan tubuh, memberikan perlindungan, pencegahan serta membangun kekebalan tubuh terhadap berbagai penyakit menular dan berbahaya yang bisa berakibat kecacatan bahkan kematian. ${ }^{6}$ Peran seorang ibu pada program imunisasi sangatlah penting. ${ }^{1}$ Faktor yang mempengaruhi imunisasi salah satunya adalah pendidikan. Peran seorang ibu pada program imunisasi sangatlah penting. Karenanya suatu pemahaman tentang program ini amat diperlukan. Pemahaman ibu atau pengetahuan ibu terhadap imunisasi sangat dipengaruhi oleh tingkat pendidikan ibu. ${ }^{1}$

Tidak adanya perbedaan kelengkapan imunisasi antara ibu yang bekerja dengan ibu yang tidak bekerja dapat disebabkan oleh persamaan tingkat pendidikan diantara kedua kelompok tersebut yang sebagian besar SMA dan Perguruan Tinggi, ibu yang bekerja maupun yang tidak bekerja apabila berpendidikan tinggi, mereka tetap memiliki pengetahuan yang baik, sehingga dapat memilih dan membuat keputusan dengan baik.

\section{SIMPULAN}

Berdasarkan hasil uji statistik tidak ada perbedaan dalam kelengkapan imunisasi bayi antara ibu yang bekerja dengan yang tidak bekerja.

\section{SARAN}

Bagi ibu tetap harus berperan dan bertanggung jawab untuk kelengkapan imunisasi bayinya, apabila ibu bekerja dapat dilakukan setelah mereka pulang bekerja.

Penelitian selanjutnya diharapkan menyeimbangkan jumlah ibu yang bekerja dengan yang tidak bekerja dan menambah jumlah sampel.

\section{KEPUSTAKAAN}

1. Ali, M. 2003. Pengetahuan, Sikap dan Perilaku Ibu Bekerja dan Ibu Tidak Bekerja Tentang Imunisasi. Tesis FK USU. Tidak Dipublikasikan.

2. Wulandari, Putri D. A. 2013. Hubungan Peran Ibu Dengan Kelengkapan Imunisasi Dasar Pada Bayi Usia 9-12 Bulan Di Posyandu Cempaka Rw 05 Sidomulyo Kelurahan Sidotopo Wetan Kecamatan Kenjeran Surabaya. Karya Tulis Ilmiah DIII Keperawatan. Akademi Keperawatan Adi Husada. Tidak Dipublikasikan.

3. Soelaeman, R. 2011. Pentingnya Imunisasi Bagi Si Kecil. www.tabloidnova.com. Tanggal akses 15 Januari 2014. Jam akses 09.00 WIB.

4. Rahmawati, Adzaniyah Isyani Rahmawati, dan Umbul, Chatarina. 2014. Faktor Yang Mempengaruhi Kelengkapan Imunisasi Dasar Di Kelurahan Krembangan Utara. Jurnal Berkala Epidemiologi. 6(1):59-70.

5. Ranuh, I.G.N., Suyitno, H., Hadinegoro, S.R., Kartasasmita, C.B., Ismoedijanto, Soedjatmiko. 2011. Pedoman Imunisasi di Indonesia. Jakarta : Satgas Imunisasi IDA.

6. Soedjatmiko. 2008. Imunisasi Penting Untuk Mencegah Penyakit Berbahaya. www.yayasan.kesejahteraan.anakindonesi a.htm. Tanggal Akses 15 Januari 2014. Jam akses 09.30 WIB. 